\title{
Evaluating Groundwater Discharge Using Age-Dating Tracers
}

\author{
C.E. HUMPHREY ${ }^{1 *}$, D.K. SOLOMON ${ }^{1}$, \\ A.R. MITTELSTET ${ }^{2}$, T.E. GILMORE ${ }^{2}$ \\ ${ }^{1}$ Geology and Geophysics, University of Utah, SLC, UT \\ 84121, USA (*correspondence: c.humphrey@utah.edu, \\ kip.solomon@utah.edu) \\ ${ }^{2}$ College of Natural Resources, University of Nebraska, \\ 68583,USA (amittelstet2@unl.edu, gilmore@unl.edu)
}

\section{Geochemical Tracers in Groundwater Systems}

Groundwater transit time distributions (TTDs) are critical for understanding contaminant flushing from aquifers to streams and can provide insight into spatial patterns of recharge rates. While models of shallow groundwater systems are commonly assumed to discharge higher fractions of young groundwater into a stream (e.g. an exponential TTD), few field-based observations of the TTD have been reported [1,2]. In this study, we observe the TTD at watershed scale (13 to $4,000 \mathrm{~km}^{2}$ ) based on flow-weighted tracer data using noble gases, ${ }^{3} \mathrm{H}$, and ${ }^{14} \mathrm{C}$ age-dating techniques at 100 streambed locations to better relate groundwater age distributions to observable hydrologic characteristics.

\section{Unique Approach to flow-weighted TTD}

Groundwater samples were collected from piezometers installed $30-50 \mathrm{~cm}$ into the streambed of the south branch of the Middle Loup River in the Sand Hills, USA. At each of the sampling locations, the rate of groundwater discharge into the stream was measured using a tube seepage meter (TSM); a novel device that can directly measure seepage rates with relatively low uncertainty. Using these seepage rates and the ${ }^{3} \mathrm{H} /{ }^{3} \mathrm{He}$ dating method, we have computed flow-weighted TTDs for both high (ca. $1.00 \mathrm{~m}^{3} / \mathrm{s}$ ) and low (ca. $0.08 \mathrm{~m}^{3} / \mathrm{s}$ ) stream-flow conditions. During high-flow conditions we observed transit times of 0 to more than 70 years while under baseflow conditions, we observed transit times ranging from 40 to more than 70 years: the limit of the ${ }^{3} \mathrm{H} /{ }^{3} \mathrm{He}$ age-dating method. To age-date water older than 70 years, we supplement analysis with other geochemical tracers such as ${ }^{14} \mathrm{C}$. A gamma distribution with a shape factor $(\alpha)$ greater than 1 was fit to both data sets and implies a lack of young water that would be predicted by an exponential TTD. This has significant implications for the transport of groundwater contaminants to streams as the lack of young (short) travel paths implies very long flushing times.

[1] Browne \& Guldan (2005) JEQ 34, 825-35.

[2] Gilmore et al. (2016) WRR 52(3), 2025-2044. 